\title{
CLINICOPATHOLOGIC STUDY OF BASAL CELL CARCINOMA: A SINGLE-CENTRE RETROSPECTIVE STUDY
}

\author{
By \\ Ahmed Mustafa Abd El-Wahab Al-Bayomi, Hussein Mohamed Hassab \\ El-Naby and Mohammed Abd El-Mawgoud Amer \\ Department of Dermatology, Venereology and Andrology, \\ Faculty of Medicine, Al-Azhar University \\ Corresponding Author: Ahmed Mustafa Abdelwahab Albayomi, \\ Phone: +201066190192, E-mail: a7madsasa@gmail.com
}

\begin{abstract}
Background: Basal cell carcinoma (BCC) is the most common malignant neoplasm in fair-skinned individuals and accounts for about two-thirds of all skin cancers in Caucasians. BCC rarely metastasizes or causes death, but it can result in extensive morbidity through local invasion and tissue destruction.

Objective: To evaluate the clinicopathologic features of basal cell carcinoma in Egyptian population.

Patients and methods: Our study included 80 patients with BCCs from January 2015 to December 2019. A retrospective analysis of baseline clinical and histopathological data was for all subjects incorporated in the study. Data needed for the study were obtained from the case files. Patients were histologically diagnosed at Dermatopathology unit of Department of Dermatology and Venereology, Al-Hussein University Hospital, Cairo, Egypt.

Results: The present study showed that the clinical types of BCC of the involved patients were 41 lesions (39\%) of ulcerative type, 39 lesions (37.1\%) of nodular non pigmented type, 13 lesions (12.4\%) of nodular pigmented type, 9 lesions (8.6\%) of superficial type, and 3 lesions $(2.9 \%)$ of advanced type. As regards the histological subtypes, 52 lesions (49.5\%) were nodular, 11 lesions (15.9\%) were pigmented, 9 lesions $(8.6 \%)$ were adenoid, 9 lesions $(8.6 \%)$ were superficial, 8 lesions (7.67\%) were infiltrative, 7 lesions $(6.7 \%)$ were micro-nodular, 6 lesions (5.7\%) were nodulo-cystic and 3 lesions (4.3\%) were baso-squamous.
\end{abstract}

Conclusion: Based on our findings, BCC was strongly associated with exposure to ultraviolet (UV) radiations. Tumors developed mainly on the sun-exposed skin of elderly individuals. Nodular BCC was the most common clinical and histological subtype.

Keywords: Clinicopathologic Study, Basal Cell Carcinoma, Retrospective Study.

\section{INTRODUCTION}

Basal cell carcinoma (BCC) is a common malignant skin tumor in humans, and its incidence is increasing. In the United States, approximately one million new cases are annually diagnosed. This cutaneous malignancy never metastasizes, but is locally destructive (Puig and Berrocal, 2015).

Approximately $80 \%$ of all BCC occur on the head and neck. The clinical diagnosis of typical BCC is relatively straightforward. Early BCCs are usually small, pearly with raised telangiectatic thread-like margin produced by slowly 
progressive peripheral extension. More advanced lesions can present as rodent ulcer with an ulcerated centre and an indurated edge (Madan and Lear, 2016).

Basal cell carcinoma can be classified into five main clinical subtypes: nodular, superficial, morphoeic, pigmented and fibroepithelioma of Pinkus. Generally, these clinical subtypes correlate with their respective histopathologic growth patterns (Nagarajan et al., 2020).

Nodular/nodulocystic BCC is the commonest subtype of BCC. It presents as a smooth pearly papule with surface telangiectasia. Head and neck is the most common site for this variant. It may have cystic centres, which add to the translucent appearance. The lesion develops a rolled border as it enlarges. Ulceration is common and may become the dominant characteristic (Pyne et al., 2017).

BCCs also can be classified into two broad categories on the basis of histopathologic features: indolent-growth and aggressive-growth subtypes. Indolentgrowth subtypes include nodular and superficial, corresponding to the clinical nodular and superficial subtypes, respectively. Aggressive-growth subtypes, which have a higher recurrence rate and tend to cause extensive local destruction, include morpheaform, infiltrative, micronodular and basosquamous (Calonje et al., 2020).

A biopsy is the only way to definitively diagnose BCC. Various biopsy techniques may be used, including excisional, incisional, shave and punch biopsies. Punch and shave biopsies have been shown to have similar diagnostic accuracy (Haws et al., 2012).
The goal of treatment of BCC is to completely remove the tumor and preserve function and cosmesis at the site of treatment. Choice of treatment depends in large part on the risk of lesion recurrence, which in turn depends on the presence or absence of aggressive clinical and histopathologic features. Another important consideration for treatment choice is location of the lesion. Patient preference after a discussion of the risks and benefits of various modalities is also an important consideration in treatment selection (Miller et al., 2010).

The aim of this work was to evaluate the clinicopathologic features of basal cell carcinoma in Egyptian population.

\section{PATIENTS AND METHODS}

This study included 80 patients with various types of BCCs from January 2015 to December 2019. The patients were histologically diagnosed at Dermatopathology unit. The patients were able to read and give consents. Patients with incomplete records or patients originating from geographical areas other than Egypt were excluded. Biopsy samples were obtained at Dermatopathology unit of Department of Dermatology and Venereology, AlHussein University Hospital, Cairo, Egypt.

We retrospectively reviewed the medical records and the pathology archive to obtain the baseline clinical and histopathological data needed for the study. Demographic data such as age, sex, sun exposure and Fitzpatrick skin type were collected for each patient and correlated to clinical and histopathological parameters. 
A presence of $\geq 2$ primary tumors in a single patient was considered BCC multiplicity (multiple BCC subgroup). When a patient had only one primary $\mathrm{BCC}$, the case was assigned to single $\mathrm{BCC}$ subgroup.

Biopsy material was fixed in buffered formalin, embedded in paraffin blocks and stained with hematoxylin and eosin.

The clinical and histopathological classification of BCC subtypes was done using the Rook's Textbook of Dermatology classification system (Madan and Lear, 2016).

\section{Statistical analysis:}

Results of the present study were statistically analyzed using Statistical Program for Social Science (SPSS) version (IBM, USA). Quantitative data were expressed as mean \pm standard deviation (SD). Qualitative data were expressed as frequency and percentage.

\section{RESULTS}

A total of 80 patients with a total of 105 histologically proven primary BCCs were assessed.

As regards the age of the patients, it ranged from 22-84 years with a mean age of $59.7 \pm 13.4$ years. As regard sex, they were 46 males $(57.5 \%)$ and 34 females $(42.5 \%)$. According to the duration of $\mathrm{BCC}$, the mean disease duration in all studied patients was $3.1 \pm 3.7$ years with minimum duration of 0.25 year and maximum duration of 20 years. As regards the sun exposure, 57 patients $(71.2 \%)$ reported daily sun exposure and 23 patients $(28.8 \%)$ reported interrupted sun exposure. Regarding the Fitzpatrick's skin type of involved patients, 4 patients (5\%) had skin type II, 46 patients $(57.5 \%)$ had skin type III and 30 patients $(37.5 \%)$ had skin type IV (Table 1).

Table (1): Distribution of the studied patients according to demographic data

\begin{tabular}{|c|c|c|c|}
\hline \multicolumn{2}{|c|}{ Parameters } & \multirow{2}{*}{\multicolumn{2}{|c|}{$\begin{array}{c}\text { Studied patients } \\
(\mathbf{N}=\mathbf{8 0})\end{array}$}} \\
\hline \multirow{2}{*}{ Age (years) } & Min - Max & & \\
\hline & Mean \pm SD & \multicolumn{2}{|c|}{$59.7 \pm 13.4$} \\
\hline \multirow{2}{*}{ Sex } & Male & 46 & $57.5 \%$ \\
\hline & Female & 34 & $42.5 \%$ \\
\hline \multirow{2}{*}{ Duration (years) } & Min - Max & \multicolumn{2}{|c|}{$0.25-20$} \\
\hline & Mean \pm SD & \multicolumn{2}{|c|}{$3.1 \pm 3.7$} \\
\hline \multirow{2}{*}{ Sun exposure } & Daily & 57 & $71.2 \%$ \\
\hline & Interrupted & 23 & $28.8 \%$ \\
\hline \multirow{3}{*}{ Fitzpatrick skin type } & II & 4 & $5 \%$ \\
\hline & III & 46 & $57.5 \%$ \\
\hline & IV & 30 & $37.5 \%$ \\
\hline
\end{tabular}

Regarding number of tumors per individual, of all the 80 patients who entered the study, 69 patients $(86.25 \%)$ had single BCC and 11 patients $(13.75 \%)$ had multiple BCCs. Among 105 lesions, there were 69 lesions $(65.7 \%)$ in the single BCC subgroup and 36 lesions (34.3\%) in the multiple BCC subgroup (Table 2). 
Table (2): Distribution of the studied patients according to number of tumors per individual

\begin{tabular}{|c|c|c|c|c|}
\hline Parameters & \multicolumn{2}{|c|}{$\begin{array}{c}\text { Studied patients } \\
(\mathbf{N}=\mathbf{8 0})\end{array}$} & \multicolumn{2}{c|}{$\begin{array}{c}\text { Studied lesions } \\
(\mathbf{N =} \text { 105) }\end{array}$} \\
\hline Single BCC & 69 & $86.25 \%$ & 69 & $65.7 \%$ \\
\hline Multiple BCCs & 11 & $13.75 \%$ & 36 & $34.3 \%$ \\
\hline
\end{tabular}

According to the tumor location, there were 80 lesions $(76.2 \%)$ in the head, 17 lesions $(16.2 \%)$ in the trunk and 8 lesions $(7.6 \%)$ in the extremities. Concerning the clinical types of $\mathrm{BCC}$, there were 41 lesions (39\%) of ulcerative type, 39 lesions $(37.1 \%)$ of nodular non pigmented type, 13 lesions (12.4\%) of nodular pigmented type, 9 lesions (8.6\%) of superficial type and 3 lesions $(2.9 \%)$ of advanced type. As regards the histological subtypes, 52 lesions $(49.5 \%)$ were nodular, 11 lesions $(15.9 \%)$ were pigmented, 9 lesions $(8.6 \%)$ were adenoid, 9 lesions $(8.6 \%)$ were superficial, 8 lesions $(7.67 \%)$ were infiltrative, 7 lesions $(6.7 \%)$ were micro-nodular, 6 lesions $(5.7 \%)$ were nodulo-cystic and 3 lesions (4.3\%) were baso-squamous (Table 3).

Table (3): Distribution of the studied lesions according to clinicopathological characteristics

\begin{tabular}{|c|c|c|c|}
\hline \multicolumn{2}{|c|}{ Parameters } & \multicolumn{2}{|c|}{$\begin{array}{l}\text { Studied lesions } \\
(\mathrm{N}=\mathbf{1 0 5})\end{array}$} \\
\hline \multirow{3}{*}{ Site } & Head & 80 & $76.2 \%$ \\
\hline & Trunk & 17 & $16.2 \%$ \\
\hline & Extremities & 8 & $7.6 \%$ \\
\hline \multirow{5}{*}{ Clinical types } & Ulcerative & 41 & $39 \%$ \\
\hline & Nodular (non-pigmented) & 39 & $37.1 \%$ \\
\hline & Nodular (pigmented) & 13 & $12.4 \%$ \\
\hline & Superficial & 9 & $8.6 \%$ \\
\hline & Advanced & 3 & $2.9 \%$ \\
\hline \multirow{8}{*}{ Histological subtypes } & Nodular & 52 & $49.5 \%$ \\
\hline & Pigmented & 11 & $10.5 \%$ \\
\hline & Adenoid & 9 & $8.6 \%$ \\
\hline & Superficial & 9 & $8.6 \%$ \\
\hline & Infiltrative & 8 & $7.6 \%$ \\
\hline & Micro-nodular & 7 & $6.7 \%$ \\
\hline & Nodulo-cystic & 6 & $5.7 \%$ \\
\hline & Baso-squamous & 3 & $2.9 \%$ \\
\hline
\end{tabular}




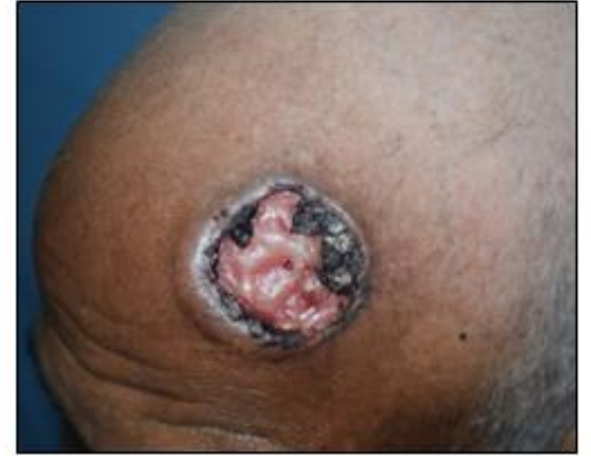

Figure (1): Ulcerative BCC on the scalp showing central ulceration and rolled border.

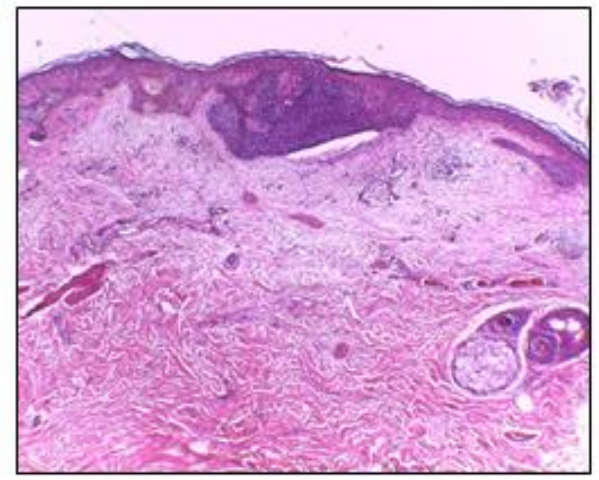

Figure (3): Superficial BCC showing islands of basaloid cells confined to the papillary dermis.

\section{DISCUSSION}

In the present study, we retrospectively reviewed 80 patients presented by different types of BCC on the head, trunk and scalp. Their ages ranged from 22-84 years with a mean age of $59.7 \pm 13.4$ years. There were 52 patients $(65 \%)>60$ years, which matches the data of Bartos and Kullová (2017) who reported that $78.2 \%$ of BCC occur over age of 60 years.

According to gender, our study included 46 males (57.5\%) and 34 females $(42.5 \%)$ which agreed with Seidenari et al. (2014) who found that there was a male predominance that may be due to more frequent exposure of males

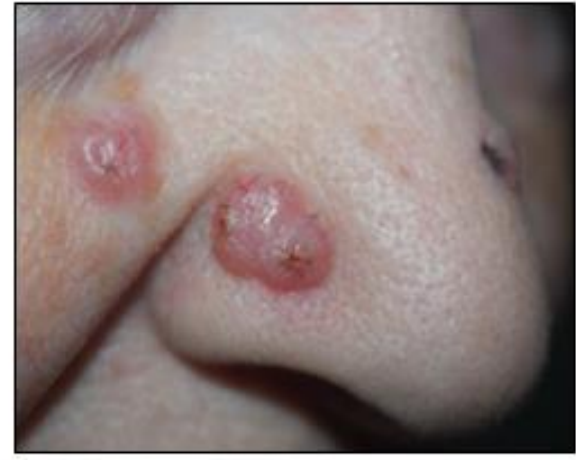

Figure (2): Nodular BCC on the nose showing pink nodule with surface telangiectasia.

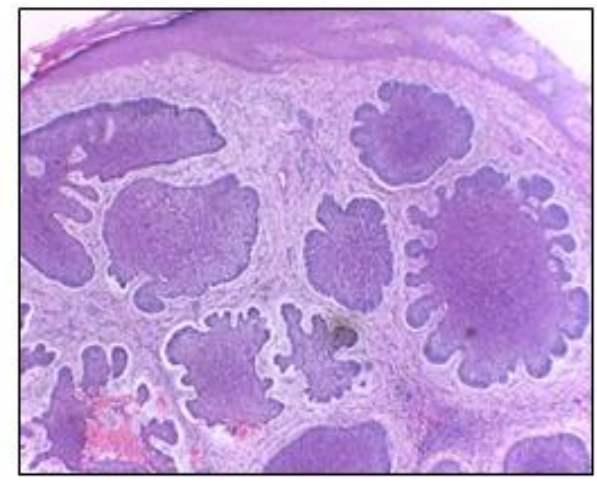

Figure (4): Nodular BCC showing well-circumscribed masses of basaloid cells.

to UVR which is related to the nature of their outdoor work.

Concerning sun exposure, 23 patients (28.8\%) reported interrupted sun exposure and 57 patient $(71.2 \%)$ reported daily sun exposure which agreed with other studies that reported sun exposure as the major cause of BCC (Zhang et al., 2012).

According to the duration of $\mathrm{BCC}$ of the involved patients , 35 patients $(43.8 \%)$ reported an onset of $\leq 1$ year while 45 patients $(56.2 \%)$ reported an onset of more than 1 year with a mean duration of $(3.1 \pm 3.7)$ years. This long duration may be explained by the slow growth rate of BCC (Madan and Lear, 2016). 
Regarding the Fitzpatrick's skin type of involved patients, 4 patients $(5 \%)$ had skin type II, 46 patients $(57.5 \%)$ had skin type III and 30 patients (37.5\%) had skin type IV. This result agreed with Verkouteren et al. (2017) who stated that, although BCC most commonly presents on the sun-exposed regions of fair-skinned individuals, it has been reported infrequently in dark skinned patients.

Regarding the clinical types of BCC, 52 patients $(49.5 \%)$ had nodular BCC. This result goes hand by hand with the fact that nodular BCC is the most common type (Nagarajan et al., 2020).

According to the tumor location, there were 80 lesions $(76.2 \%)$ in the head, which matches the data of Bartos and Kullová (2017) who reported that $68.8 \%$ of BCCs were located on the head and neck region agreeing with being the most common areas exposed to sun.

As regards the histological subtypes, 52 lesions $(49.5 \%)$ were nodular, which matches the data of Bartos and Kullová (2017) who reported that $40.3 \%$ of BCCs was nodular.

\section{CONCLUSION}

BCC was strongly associated with exposure to ultraviolet (UV) radiations. Tumors develop mainly on the sunexposed skin of elderly individuals. Men are more frequently affected than women. Nodular BCC is the most common clinical and histological subtype.

Conflicts of interest: no conflicts of interest were encountered.

\section{REFERENCES}

1. Bartos $V$ and Kullová $M$ (2017): Basal Cell Carcinoma Multiplicity - a Retrospective Analysis of 899 Biopsyproven Patient from a Single Institute. Klin Onkol., 30(3): 197-201.

2. Calonje E, Brenn T, Lazar $A$ and Billings S (2020): McKee's Pathology of the Skin. 5th ed. Pbl. Elsevier, 11701188.

3. Haws AL, Rojano R, Tahan SR and Phung TL (2012): Accuracy of biopsy sampling for subtyping basal cell carcinoma. Journal of the American Academy of Dermatology., 66(1): 106111.

4. Madan V and Lear JT (2016): Basal Cell Carcinoma. Rook's Textbook of Dermatology. 9th ed. Pbl. Oxford, UK: Wiley-Blackwell, 141.

5. Miller SJ, Alam M, Andersen J, Berg D, Bichakjian CK, Bowen G, Cheney RT, Glass LF, Grekin RC, Kessinger $A$ and Lee NY (2010): Basal cell and squamous cell skin cancers. Journal of the National Comprehensive Cancer Network, 8(8): 836-864.

6. Nagarajan P, Tetzlaff MT and Curry JL (2020): Histopathology of Basal Cell Carcinoma and Its Variants. Basal Cell Carcinoma. Pbl. Cham, Switzerland: Springer., 25-48.

7. Puig $S$ and Berrocal A (2015): Management of high-risk and advanced basal cell carcinoma. Clinical \& Translational Oncology, 17(7): 497503.

8. Pyne JH, Myint E, Barr EM, Clark SP, David $R$ and Hou $R$ (2017): Superficial basal cell carcinoma: 
comparisons of superficial only subtype with superficial combined with other subtypes by age, sex and anatomic site in 3150 cases. Journal of Cutaneous Pathology, 44(8): 677-683.

9. Seidenari S, Bellucci C, Bassoli S, Arginelli F, Magnoni $\mathrm{C}$ and Ponti G (2014): High magnification digital dermoscopy of basal cell carcinoma: a single-centre study on 400 cases. Acta Dermato-Venereologica, 94(6): 677682.
10. Verkouteren J, Ramdas $\mathbf{K}$, Wakkee $M$ and Nijsten $T$ (2017): Epidemiology of basal cell carcinoma: scholarly review. The British Journal of Dermatology, 177(2): 359-372.

11. Zhang M, Qureshi AA, Geller AC, Frazier L, Hunter DJ and Han J (2012): Use of tanning beds and incidence of skin cancer. Journal of clinical oncology: official journal of the American Society of Clinical Oncology, 30(14): 1588-1593. 


\section{دراسة إكلينيكية باثولوجية لسرطان الخلايا القاعدية: دراسة

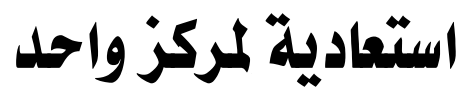

أحمد مصطفى عبد الوهاب البيومي، حسين محمد حسب النبي، محمد عبد الموجود عامر

قسم الأمراض الجلدية والتناسلية وأمراض الذكورة، كلية الطب، جامعة الأزهر

E-mail: $\underline{\text { a7madsasa@gmail.com }}$

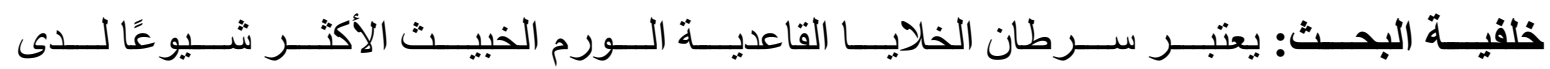

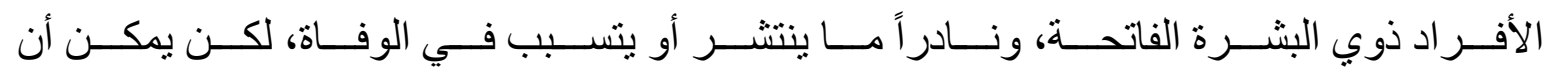

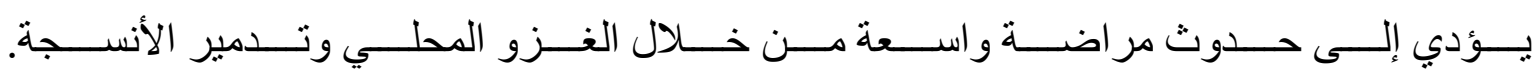

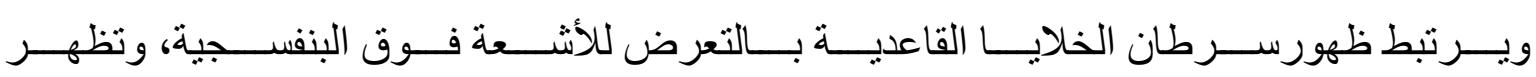

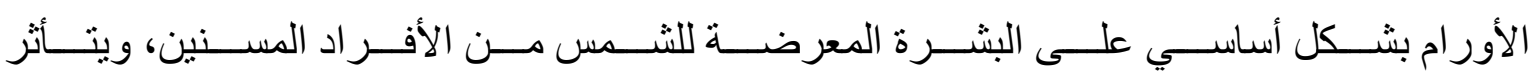

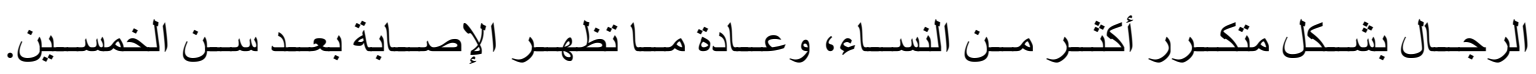

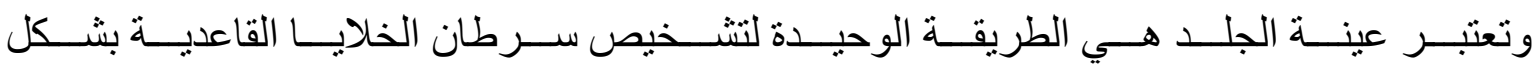
نهائي.

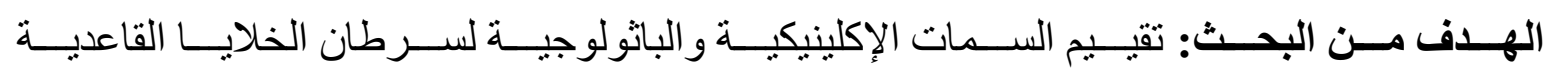
في السكان المصريين.

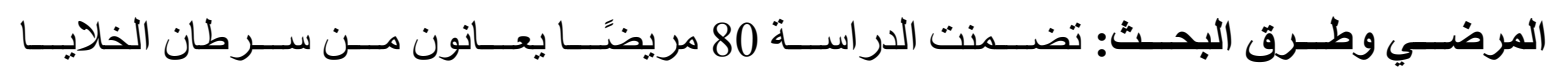

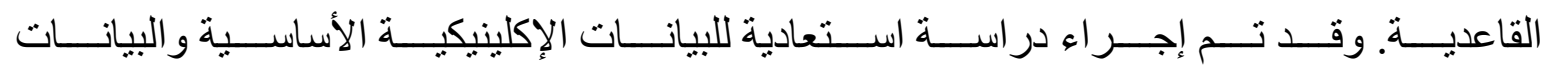

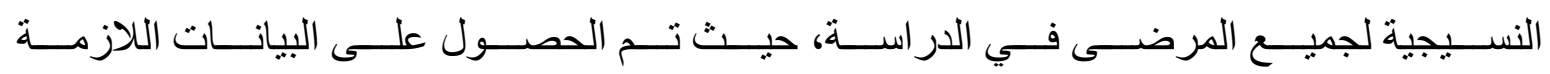
للار اسة من ملفات المرضى الخاصة بوحدة باثولوجيا الجلد.

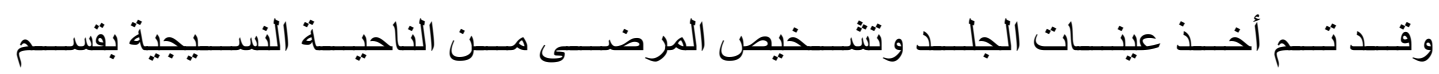

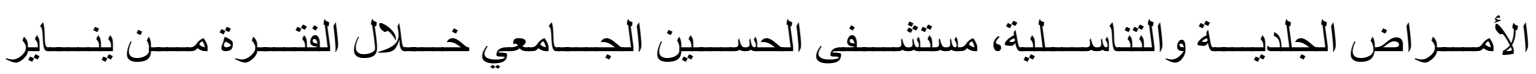
2015 حتى ديسمبر 2019.

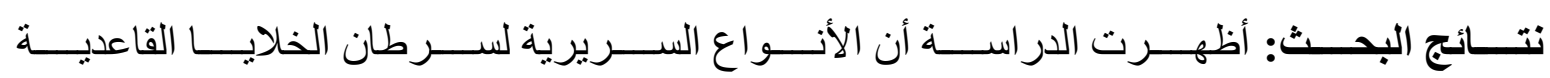

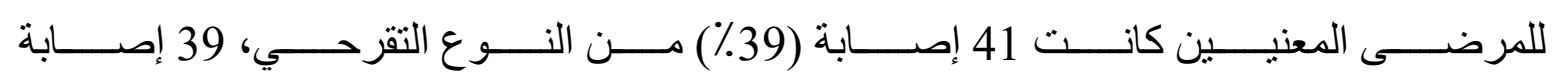




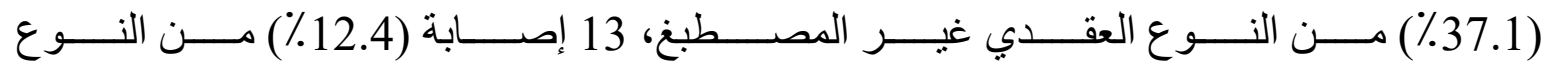

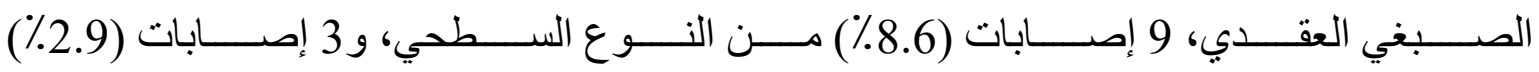

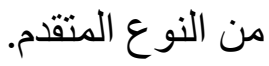

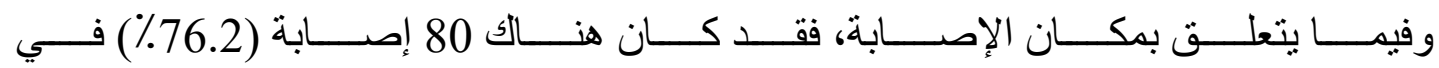
الر أس، 17 إصابة (16.2\%) في الجذع و8 إصابات (7.6٪) في الأطر اف.

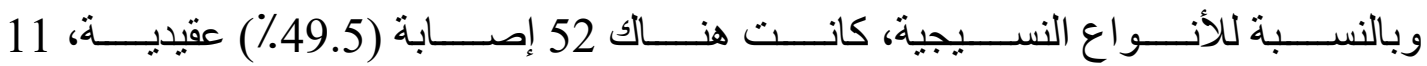

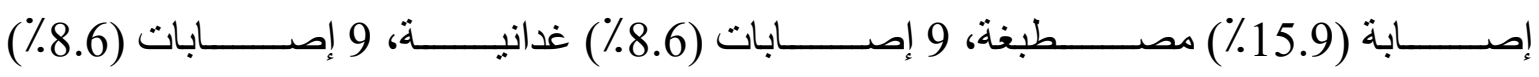

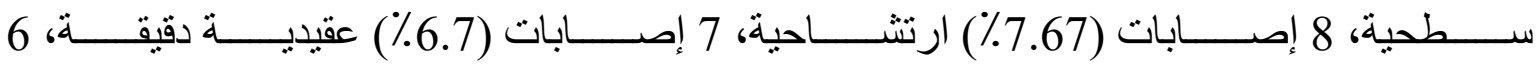
إصابات (5.7\%) عقيدية كيسية، 3 إصابات (4.3\%) قاعدية حرشفية.

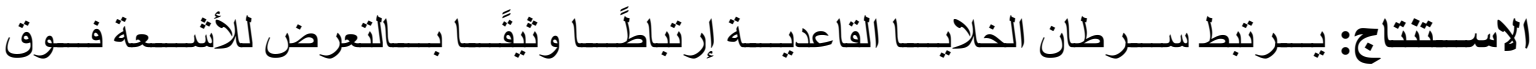

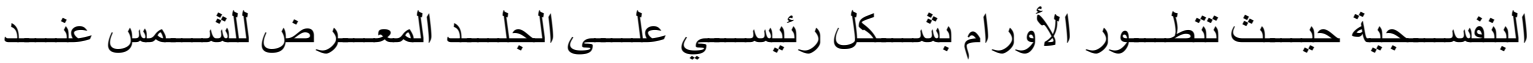

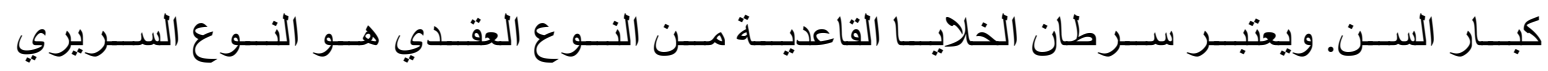

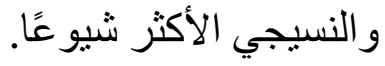

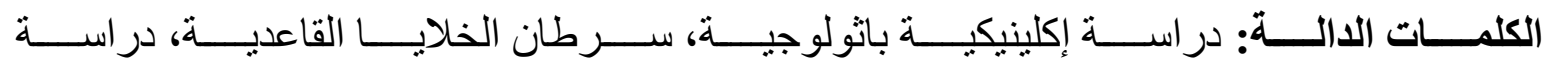

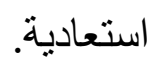

